\title{
GLAGOLJAŠI U SPLITU U 15. STOLJEĆU
}

\author{
Petar Runje
}

UDK: 003.349.1:27.772.5 (497.583Split)“14“

https://doi.org/10.34075/cs.55.1.4

Prethodno priopćenje

Rad zaprimljen 4/2019.

\section{Sažetak}

U članku se iznose podaci pronađeni $u$ bilježničkim spisima iz 15. stoljeća o knjizi na hrvatskom jeziku u osobnoj knjižnici splitskoga arhiprezbitera i o nekim svećenicima glagoljašima tada nastanjenima u gradu Splitu. Posebnoje značenje tih podataka u tome što neki drugi iz srednjega vijeka koji bi sujedočili o nazočnosti i djelovanju glagoljaša u samom sjedištu Splitske nadbiskupije, nisu do sada pronađeni.

Ključne riječi: Glagoljaši u Splitu, knjiga na hrvatskom jeziku, svećenik glagoljaš Ilija Milunić, svećenik glagoljaš Grgo, svećenik Tomaš pretpostavljeni glagoljaš

\section{UvOD}

Etnička struktura dalmatinskih gradova posljednjih stoljeća srednjega vijeka mijenja se u korist hrvatskog pučanstva. Kako je pučanstvo u 15. stoljeću u gradovima pretežno hrvatsko, jer se je stalno naseljavalo u gradove, tako je i jezik u gradovima bivao sve više hrvatski. Službeni jezik kancelarije za vrijeme mletačke uprave bio je latinski, a na sudovima i u javnim procesima bio je u uporabi i talijanski, ali i hrvatski jezik. ${ }^{1}$ Grad Split do sada kao da je ostao bez

NAPOMENA: Fra Petar Runje, član Provincija franjevaca trećoredaca glagoljaša, rođen je u Karakašici kod Sinja 9. svibnja 1938. Nekoliko je gimnazijskih razreda pohađao u Sjemenišnoj gimnaziji u Splitu, ostale dijelom u takvim gimnazijama u Zadru i Zagrebu. Filozofsko-bogoslovni studij diplomirao je na KBF-u u Zagrebu. Za svećenika je zaređen 1964. Na Filozofskom fakultetu u Zadru pohađao je poslijediplomski studij pomoćnih povijesnih znanosti. Boraveći u zadarskom samostanu svoje provincije, onom sv. Mihovila, istraživao je tijekom više godina u slobodno vrijeme notarske spise sačuvane u Državnom arhivu u Zadru, u kojima je ponajviše tražio podatke o glagoljanju i glagoljašima na širem zadarskom području. Rezultate tog istraživanja objavio je u nizu knjiga i članaka. Umro je u Odri pokraj Zagreba 16. prosinca 2014. Dok je boravio u Zadru, uspio je pregledati i neke sveske splitskih notara iz kasnoga srednjeg vijeka koji se čuvaju 
ikakvih tragova glagoljaša u srednjem vijeku. Međutim, kako je u samom zaleđu Splita u bogoslužju bio u uporabi staroslavenski jezik, posebno u poljičkom i radobiljskom kraju, onda je doista neobično da i u samom gradu Splitu nije ostalo više očitih tragova nazočnosti svećenika glagoljaša i možebitne glagoljaške književne produkcije. ${ }^{2}$

Ovdje kanim pribilježiti barem sitne tragove glagoljaša i u samome Splitu. U inventaru dobara od 27. siječnja 1435. pok. Lovre, arhiprezbitera splitskoga, među ostalim dobrima i knjigama nalazi se i jedna mala knjiga napisana na hrvatskom jeziku, "in lettera sclava". ${ }^{3}$ Budući da se ne veli izričito da je duhovnoga sadržaja, mogla je biti i svjetovnoga, ali, u svakom slučaju, pisana je hrvatskim jezikom. Ako je splitski arhiprezbiter upotrebljavao i imao knjigu na hrvatskom jeziku, onda je pretpostaviti da su i drugi svećenici, posebno obični svećenici nižih položaja u crkvenim strukturama, mogli imati i upotrebljavati na hrvatskom jeziku knjige pa i u dnevnoj službi kod oltara. Čini se da upravo u tom smislu možemo navesti barem dvojicu svećenika glagoljaša u Splitu u polovici 15. stoljeća.

O svećeniku Iliji, glagoljašu u Splitu, imamo nešto više podataka. Prvi put 8. siječnja 1442. pribilježio sam spomen o svećeniku Iliji s dodatkom "Sclavus", kada on prima na čuvanje stotinu libara od Ivana Senkovića. ${ }^{4}$ Godine 1443., dana 4. rujna, Ilija Milunić "presbiter Sclavus habitator Spalati" prodaje Ivanu Kuzmiću vinograd kod Sv. Trojice za stotinu i deset libara i svjedoči da je primio novac; prisutni svjedoci kod ovoga ugovora su Juraj Matejev i Radoslav, placario, stanovnici Splita. ${ }^{5} \mathrm{~S}$ tim dokumentom doznajemo i za pravo prezime svećenika Ilije: "Milunić", koji je zacijelo nastanjen u Splitu te ima posjede u neposrednoj okolici Splita. Nakon nekoliko mjeseci ponovo se spominje "Dominus Elias presbiter Sclavus" u Splitu, kada on prima dvadeset libara, što mu je u oporuci ostavio pokojni Dminko Omović. ${ }^{6} \mathrm{U}$ arhivskim bilježničkim spisima Split-

u spomenutom arhivu. Kratak članak o glagoljaškim tragovima u gradu Splitu namijenjen časopisu Crkva u svijetu poslao je 3. prosinca 1995., ali se tada zagubio. Tek nedavno je pronađen.

1 Usp. MARKO ŠUNJIĆ, Dalmacija u XV. stoljeću, Sarajevo, 1967., posebno vidi poglavlje „Etnička struktura Mletačke Dalmacije“, na str. 276ss.

2 Glavni je razlog te praznine u tome što serije spisa Nadbiskupskoga arhiva i drugih crkvenih arhiva iz tih davnih stoljeća nisu sačuvani. Poznato je da je Nadbiskupska kancelarija u kojoj se čuvalo arhivsko gradivo g. 1506. stradala u požaru. Arhiv HAZU, Sign. II. d 155, sveščić 1, 27. I. 1435. “Item libro uno pizolo in lettera sclava”.

4 Povijesni arhiv Zadar (unaprijed: PAZ), Splitski arhiv, Kutija 8, sveščić 2, 8. I. 1442. "Dominus Elias presbiter Sclavus...."

5 PAZ, Splitski arhiv, Kutija 8, sveščić 2, 4. IX. 1443.

6 DAZD, Splitski arhiv, Kutija 8 sveščić 2, 14.-IV. 1444. 
ske komune tijekom deset godina dosta često spominje se svećenik Ilija "de lettera sclava" u Splitu.

Zanimljivo je da se 25. lipnja 1455. u službenom dokumentu pojavljuje uz svećenika "Elias de littera sclava”, koji prima novac iz oporuke pokojne Margarete Bivaldi, i svjedok Pavao klerik. Dokument je i napisan u kući svećenika Ilije i tu je prisutan kao svjedok Pavao klerik "de Clissio". ${ }^{7}$ Budući je dokument pisan u kući svećenika Ilije, smatram da je i klerik Pavao zapravo njegov klerik koji je iz okolice Klisa. A to znači da je Ilija, svećenik glagoljaš, u nekoj od splitskih crkava vršio službu i brinuo se za odgoj i školovanje svećenika svojih nasljednika.

Uz svećenika Iliju i njegova klerika Pavla nalazimo spomen i o svećeniku Grgi glagoljašu u Splitu baš u to vrijeme. Pribilježio sam podatak 5. veljače 1454. "Testamentum Venerabilis viri domini presbiteri Gregorii in littera sclava clausum et sigilatum secundum (...). Spalati (...)"8 Prema tom nepotpunom uvidu nije moguće odrediti je li i gdje je služio Grgo, glagoljaš u Splitu. Nadati se je da bi se i iz same oporuke moglo naći neku informaciju više.

Možda je također vrijedna informacija iz godine 1444. da fra Andrija Bilobradić, franjevac iz Splita, prima od Ser Andrije Markovoga iz Splita u vlasništvo "unum missale in littera latina", s napomenom da poslije smrti dotični misal pripadne franjevcima u Bosni. ${ }^{9}$ Isti dan fra Andrija franjevac prima i od Ivana Piroševića jedan brevijar, s kojim neka se služi za života, a poslije smrti neka ga se preda franjevcima u Bosni. Za brevijar se veli da je vrijedan dvadeset zlatnih dukata. Za misal se naglašava da je "in littera latina", a za brevijar se ne navodi na kojem je jeziku i pismu. Određuje se i u ovom slučaju neka te knjige poslije njegove smrti pripadnu franjevcima u Bosni. Čini mi se da je ona oznaka za misal «in littera latina" samo upozorenje da postoje i druge knjige kojima se redovnici služe, posebno u Bosni, tj. "de littera sclava". Nekad se u arhivskim spisima navodi da je neki dokument bio napisan na hrvatskom jeziku pa preveden i službeno proknjižen na latinskom jeziku. ${ }^{10}$

7 DAZD, Splitski arhiv, Kutija 11, sveščić 5, 25. VI. 1455. "Ven. vir dominus presbiter Elias de littera sclava.... Actum in domo dicti presbiteri Elie presentibus Marco Sancovich et Paulo clerico de Clissio ect."

8 DAZD, Splitski arhiv, Kutija 10, 5. II. 1454.

9 DAZD, Splitski arhiv, Kutija, 8, sveščić 5, 8. X: 1444.

10 DAZD, Splitski arhiv, Kutija 8, sveščić 6. "Hoc est exemplum seu transumptum de littera sclava in latinum (...)” 28. I. 1445. str. 255rv. Usp. MARKO ŠUNJIĆ, nav. dj. Tu navodi nekoliko primjera o uporabi hrvatskog jezika posebno u sudskim procesima. 
Ovdje navodim i jedan zanimljiv podatak koji govori o dvije vrijedne pojedinosti. Naime 28. travnja 1454. Šimun, opat samostana sv. Andrije "de Pellago" u Splitu prima u službu na posjedima koji pripadaju samostanu sv. Andrije "de Pellago" za kapelana svećenika Tomaša "de Verbas", uz uvjet da će svećenik Tomaš za svoju kapelansku službu "in Policio" imati jednu trećinu svih prihoda što spadaju na samostan, a nema ništa od prihoda od vina jer to opat rezervira za "sibi toto vino Primorie de quo idem dominus Tomassius nullam partem habeat". ${ }^{11}$

Zanimljivo je da svećenik Tomaš “de Verbas” prihvaća službu na području Poljica i Primorja, gdje je u uporabi glagoljica. Ako je iz područja Jajca, onda nam je ovo samo još jedna potvrda da su svećenici u jajčakom kraju još u drugoj polovici 15. stoljeća upotrebljavali glagoljicu te da je Tomaš lako mogao preuzeti službu u Poljicima. Drugo, nema sumnje da su opati samostana sv. Andrije "de Pellago" imali posjed u blizini Splita, kako to na nekoliko mjesta navodi pok. don Ivan Ostojić. ${ }^{12}$ Trgovačke su i druge veze s unutrašnjosti i s Bosnom prilično dobro osvjetljene. U Splitu se je nakon pada Bosne nastanila Staniza Radoslavić te je osnovala samostan trećoredica sv. Franje (samostanskog načina života) u Splitu, pokraj crkve sv. Ciprijana godine 1483. U njemu je živjela do godine 1497., kada piše svoju oporuku. ${ }^{13}$ Godine 1498., dana 28. studenoga, svećenik Pavao pok. Žischa "de Jaiza habitator Spalati ad presens capellanus Solte” prodaje kuću s cisternom u Splitu Viktoru de Albertisu, splitskom plemicu i građaninu. ${ }^{14}$

Svećenik Pavao nije bio jedini svećenik s područja Jajca koji je u tom razdoblju boravio u Splitu. U dokumentima se pojavljuju još neki, ali početkom 16. stoljeća.

O svemu ovome nije ovdje moguće pisati, ali je vrijedno i ovo malo striktno u svezi glagoljaša u Splitu u 15. stoljeću registrirati kako bi moglo poslužiti za daljnja istraživanja. Čini se da ni Split nije ostao izvan utjecaja i susreta s glagoljašima i u mnogo obilnijem obujmu negoli nam je to dosad bilo poznato. Dobro se je podsjetiti i da je bio okružen jakim i značajnim glagoljaškim područjem.

11 DAZD, Splitski arhiv, Kutija 6, sveščić 21, 28. IV. 1454.

12 IVAN OSTOJIĆ, Benediktinci u Hrvatskoj, sv. II, Split, 1965, str. 384-387. Šimun, opat sv. Andrije "de Pelago", 16. rujna 1446. imenuje za prokuratora u Splitskoj nadbiskupiji Ser Marina Petrachu, splitskog plemića. Usp. DAZD, SZN, Nicolaus Lupovich, sv. I, sveščić 1, 16. IX. 1446.

13 PETAR RUNJE, Prema izvorima, Zagreb, 1990. U Splitu godine 1468. Božidar Vukšić iz Jajca piše u svezi sa svojim dugovima "certas litteras in sclavo". Usp. DAZD, Splitski arhiv, Kutija 14, sveščić 3, 3. IX. 1468.

14 DAZD, Splitski arhiv, Kutija 31, sveščić 43, fol. 13, 28. XI. 1498. 


\section{GLAGOLITIC PRIESTS IN SPLIT IN $15^{\mathrm{TH}}$ CENTURY}

\section{Summary}

The author emphasizes the fact that the historians so far have not discovered written traces of the presence and activities of Glagolitic priests in the centuries of the Middle Ages in the city of Split, although some traces from the area of the Archdiocese of Split have long been known. Therefore, rare information found in the writings of the 15th century is a valuable historical testimony. In this paper, they are recorded and carefully explained. There is an interesting and at least somewhat justifiable assumption about the connection between the Glagolitic priests from the area of present-day western Bosnia and Split and the area of the Archdiocese of Split.

Key words: Glagolitic priests in Split, book in Croatian language, Glagolitic priest Ilija Milunić, Glagolitic priest Grgo, priest Tomaš the presumed Glagolitic priest 